\title{
SREBRNY RELIKWIARZ ŚW. SEBASTIANA Z 1499 R.
}

Postać Johannesa Hermanna (Hermana), na przelomie XV i XVI w. kanonika wrocławskiej kapituły katedralnej, kilkakrotnie pojawia się $\mathrm{w}$ literaturze naukowej. W semestrze letnim 1450 r. Johannes Hermanni de Legnitz został immatrykulowany na wydziale artium uniwersytetu w Erfurcie ${ }^{1}$. Stopień bakałarza uzyskał tamże w semestrze zimowym r. $1456^{2} ;$ z zachowanych danych wynika, iż nie kontynuował tam studiów ${ }^{3}$. Nie ma jednak pewności, czy informacje te dotycza późniejszego kanonika. O populamości tego imienia i nazwiska na Śląsku świadczy nota proweniencyjna $\mathrm{w}$ jednym $\mathrm{z}$ inkunabułów zachowanych w Bibliotece Uniwersyteckiej we Wrocławiu, odnosząca się jednak do doktora nauk medycznych czynnego na dworze księcia legnicko-brzeskiego Joachima Fryderyka (1550-1602) ${ }^{4}$. Ów Hermann (1527-1605) zasługuje na uwage już choćby $z$ powodu poślubienia córki Lucasa Cranacha starszego ${ }^{5}$. Dysponujemy także wzmiankami o przedstawicielach rodziny o tym nazwisku w czasach późnego średniowiecza: mieszczaninie legnickim ${ }^{6}$ oraz kilku mieszkańcach Nowego Miasteczka (Neustädtel) koło Kożuchowa ${ }^{7}$.

${ }^{1} \mathrm{G}$. B a u ch, In Erfurt als Artisten promovierte Schlesier (1450-1521), „Zeitschrift des Vereins für Geschichte Schlesiens", XL, 1906, s. 326, nr 4; G. Zimmerman n, Das Breslauer Domkapitel im Zeitalter der Reformation und Gegenreformation (1500-1600). Verfassungsgeschichtliche Entwicklung und personliche Zusammensetzung (Historisch-Diplomatische Forschungen, red. L. S a n t if a 11 e r, 2), Weimar 1938, s. 294-295, poz. 82.

1456 in Quadragesima Johannes Hermann de Legenicz - B a u c h 1906. Datę 1455 podają: G. B a u c h, Beiträge zur Geschichte des schlesischen Humanismus, VI, „Zeitschrift des Vereins für Geschichte Schlesiens", XXXVIII, 1904, s. 308; Z i m m e r m a n n 1938, s. 294

${ }^{3}$ B a u c h 1906, s. 326.

${ }^{4}$ Niedatowana nota proweniencyjna: Johanny Hernanno Artis Medicae doctori suo charissimo, w inkunabule Liber pandectarum medicinae, wyd. Joannes de Colonia i Joannes Manthen, Venezia 1480 - B. K oc ow sk i, Katalog inkunabutów Biblioteki Uniwersyteckiej we Wroctawiu, 1, Wrockaw 1959, s. 797-798, poz. 2662 (dublet).

${ }^{5}$ A. W. E. T. H e n s c h e 1, Iatrologiae Silesiae specimum primum exhibens brevissimam medicorum silesiacorum saeculi XIII. ad XVI. notitiam cui catalogus medicorum Silesiae recentiorum eorumque celebriorum adiectus est prodromus edidit, Vratislaviae 1837, s. 20.

${ }^{6}$ W 1419 j 1423 wzmiankowany Niclos Hermann zu Legnicz - K. Wutk e, Die Inventare der nichtstaatliche Archive Schlesiens, II, Kreis und Stadt Glogau [Codex diplomaticus Silesiae, XXVIII], Breslau 1915, s. 58, 63.

${ }^{7}$ H. Ge rl i c, Kapitula glogowska $w$ dobie piastowskiej i jagiellońskiej (1120-1526), Gliwice 1993, s. 238, poz. 141. 
Dalsze informacje biograficzne już z cała pewnością dotyczą jednej osoby. Z końcem r. 1483 Hermann został obdarzony godnością kanonika wrocławskiej kapituły katedralnej ${ }^{8}$; w 1484 odnotowano go jako uprawnionego do objęcia kanonii ${ }^{9}$. W marcu tego samego roku rozpoczał studia prawnicze w Rzymie ${ }^{10}$, co znalazło potwierdzenie $w$ poświadczeniu od rektora tamtejszego uniwersytetu z 7 kwietnia $1484 \mathrm{rr}^{11}$. W ten sposób dostosował się do zalecenia biskupa wroclawskiego Rudolfa z Rüdedesheim z 1481 r., który w trosce o podniesienie poziomu intelektualnego kanoników, zobligowal ich do trzyletnich studiów uniwersyteckich ${ }^{12}$. W 1488 r. zapewne już od 1486 r. - Hermann używał tytułu doctor decretorum, z czego wnioskowano o jego dodatkowych studiach w Padwie ${ }^{13}$ lub Bolonii ${ }^{14}$ - najpewniej błędnie. W 1491 r. notowany wśród kanoników kapituły przy kolegiacie głogowskiej, godność tę piastował zapewne dożywotnio ${ }^{i 5}$. Pełnił też funkcję altarysty w kościele parafialnym w Legnicy ${ }^{16}$. W listopadzie $1491 \mathrm{r}$. zastapił w Rzymie dotychczasowych prokuratorów, reprezentując wrocławską kapitułę w sprawie, którą kanonik Oswald Straubinger (vel Winkler) wytoczył przed sądem papieskim biskupowi wrocławskiemu Johannowi Rothowi ${ }^{17}$. W r. 1496 objał funkcje kustosza wrocławskiej kapituły katedralnej ${ }^{18}$. W kwietniu $1503 \mathrm{r}$. został wpisany do księgi niemieckiego bractwa przy kościele Santa Maria dell'Anima w Rzymie ${ }^{19}$.

W protokole posiedzenia wrocławskiej kapituły katedralnej z dnia 16 września 1502 zapisano, iż Hermann podarował do katedry pięknie zdobiony relikwiarz ręki św. Sebastiana ze złoconego srebra, z intencją zbawienia swej duszy oraz uczczenia relikwii świętego, od czasów biskupa Hieronima (ok. 1051-1062) przechowywanych w tutejszej katedrze. Jednocześnie poprosił kapitułę, aby ustanowiła święto św. Sebastiana (20 stycznia) jako dupliciter (z trzema lekcjami); zbierana podówczas ofiara miałaby zostać przeznaczona na stypendium dla scholarów. Kanonicy przyjęli dar $\mathrm{z}$ wdzięcznością $\mathrm{i}$ aby zadośćuczynić prośbie Hermanna, obiecali współpracę $z$ biskupem (Johannem Rothem), do którego należało

${ }^{8}$ K. Do l a, Wroctawska kapituła katedralna w XV wieku, Lublin 1983, s. 355.

9 A. S a bisch, Acta Capituli Wratislaviensis 1500-1562. Die Sitzungsprotokolle des Breslauer Domkapitels in ersten Hälfte des 16. Jahrhunderts, I, 1500-1516, Köln 1972, s. LIX, poz. 16.

${ }^{10} \mathrm{~B}$ a u ch 1904 , s. 308 ; Z i mmermann 1938, s. 294; D o l a 1983, s. 355.

${ }^{11}$ D o l a 1983 , s. 355.

${ }^{12}$ Dola 1983 , s. 140 .

${ }^{13} \mathrm{Z}$ i m mermann 1938 , s. 294.

14 Z i mmerman n 1938. Johannes Hermanni Lignicensis pojawia się jako tamtejszy student między 1302 a 1305 r. - P. P f o t e n h a u e r, Schlesier auf der Universität Bologna, "Zeitcchrift des Vereins für Geschichte Schlesiens", XXVI!! 1 1894, s. 437, nr 20. W przypisie do tej wzmianki autor określa Hermanna mianem: Decretorum doctor, custos et canonicus Vratislaviensis, + 1305 feria VI. ante dominicam Palmarum (9. April) - godności i data dzienna śmierci dotycza naszego kanonika. Wiarygodność wzmianki budzi wątpliwości w świetle ustaleń podstawowej pracy na temat niemieckich studentów w Bolonii, gdzie brak interesującego nas nazwiska - G. C. K n o d, Deutsche Studenten in Bologna, Berlin 1899.

${ }^{15}$ Gerlic 1993, s. 238.

${ }^{16} \mathrm{Z}$ i m merm a n 1938 , s. 294-295.

${ }^{17} \mathrm{~J}$. D r a b in a, Kontakty Wroctawia z Rzymem w latach 1409-1517 (Prace Wroclawskiego Towarzystwa Naukowego, seria A, nr 219), Wrocław 1981, s. 156, 159.

${ }^{18} \mathrm{Z}$ i m merman n 1938 , s. 294; D o la 1983 , s. 355.

${ }^{19}$ B a u ch 1904, s. 308; Z i m merman n 1938, s. 295, przyp. 7. 
prawo ustanowienia rytu ${ }^{20}$. Jeszcze na posiedzenia kapituły po powrocie $z$ Włoch, 22 grudnia 1503 r. Hermann monitował w sprawie podniesienia rangi święta. Potwierdził swą wolę zaopatrzenia scholarów szkoły katedralnej, by ulżyć ich ciężkiemu położeniu finansowemu. Kanonicy powtómie wyrazili zadowolenie z wniosku; godzili się, aby biskup przychylił się do prośby. Powołano przykład doktora Wagnera (Waynera, zm. 1490), który sprawił, że święto św. Agnieszki (21 stycznia) obchodzono jako duplex. Kanonicy wydelegowali do biskupa dwóch przedstawicieli: Vinzenza Kindelmanna (rodem z Legnicy) oraz Nicolausa Cribela (vel Kriebela $-z$ Wrocławia $)^{21}$. Na jeđnym z kolejnych posiedzeń, 5 stycznia $1504 \mathrm{r}$. Hermann znów poprosił o ustanowienie święta duplex, argumentując, iż dał już srebrne ramię do kościoła katedralnego i zamierza dodać jedną grzywnę rocznego czynszu dla wikariuszy i scholarów. Po deliberacjach kanonicy wystapili z wnioskiem, by Hermann dał trzy grzywny rocznego czynszu na rzecz tych purpuratów, którzy wezmą udział w oficjum, jak również aby nie zabierał relikwiarza, który już poświęcony został Bogu. Wówczas Hermann oficjalnie oświadczył, iż relikwiarz zamierza sprzedać, by zadośćuczynić żądaniom kapituły. Obie strony pozostały przy swoich racjach ${ }^{22}$. Powodem braku kolejnych zapisów w tej sprawie stała się rychła śmierć Hermanna, która nastapiła 29 marca 1504 we Wrocławiu ${ }^{23}$. Dysponujemy XVIII-wiecznym odpisem inskrypcji epitafijnej z nie zachowanego do dziś grobu Hermanna w katedrze wrocławskiej ${ }^{24}$.

Wspomniany relikwiarz pozostał w skarbcu katedralnym, o czym dowiadujemy się przy okazji wypadków z końca 1563 r. 6 grudnia tego roku Maksymilian II (1527-1576), podówczas król Czech i Węgier, przybył na Śląsk, aby wziąć udział w zjeździe książęcym, mającym miejsce we Wrocławiu od 9 do 21 grudnia 1563 r. Monarcha, skądinąd religijnie indyferentny, z myślą o towarzyszącej mu żonie Marii (1528 -1603), poprosił kapitułę katedralną o pokaz relikwii znajdujących się w jej pieczy. Po długich rozważaniach kanonicy zdecydowali o okazaniu relikwii palca św. Jadwigi oraz ramienia św. Sebastiana, przechowywanego w relikwiarzu fundacji Johannesa Hermanna. Z listu biskupa wrocławskiego Caspara von Logau z 9 lutego 1564 r. do dziekanów kapituły dowiadujemy się o woli Maksymiliana pozyskania wrocławskich relikwii; tytułem rekompensaty władca obiecywał inne

${ }^{20}$ S a b is ch 1972, s. 116-117, nr 169. Fakt ten odnotowany równiez w: G. B a u c h, Geschichte des Breslauers Schulwesen vor der Reformation [Codex diplomaticus Silesiae, XXV], Breslau 1909, s. 78; Z immermann 1938, s. 295; Dola 1983, s. 161, 305; G. $\mathrm{R}$ e g u ls k a, ,Clenodia ac ornamenta ecclesiae haec erant". O pierwotnych zasobach gotyckiego złotnictwa w skarbcach kościołów na Ślasku, „Roczniki Sztuki Śląskiej”, XVI, 1997, s. 10; G. R e g u I s k a, Gotyckie ztotnictwo na Ślasku (Studia Instytutu Sztuki Polskiej Akademii Nauk, 7), Warszawa 2001, s. 16, 23.

${ }^{21} \mathrm{~S}$ a b is ch 1972 , s. 200-201, nr 261.

${ }^{22} \mathrm{~S}$ a b isch 1972 , s. 202, nr 263.

${ }^{23} \mathrm{Z}$ immermann 1938 , s. 294-295; Dol a 1983 , s. 355.

24 Anno DOMINI M.CCC.V Feria VI. ante Dominicam Palmarum, obiit Venerabilis \& eximius Vir, Dominus JOHANN. HERMANN. de Legnitz, Decretorum Doctor, CUSTOS \& CANONICUS Ecclesiae VRATISLAVIENSIS: sepultus cum Genetrice sua. Orate Deum pro eo. - Martini Hankii de Silesiis indigenis eruditis post Literarum culturam cum christianisini studiis, anno 965. susceptam ab anno 1165 ad 1550, Lipsiae 1707, s. 64, caput X; P fo te n h a u e r 1894, s. 437. Pomimo odmiennej daty rocznej nie mamy watpliwości w sprawie wiązania tej inskrypcji z naszym kanonikiem. 
relikwie lub ekwiwalent pieniężny ${ }^{25}$. W źródłach nie udało się znaleźć wzmianek o zakończeniu pertraktacji; do transakcji jednak doszło, bowiem wrocławski relikwiarz św. Sebastiana, jako dar cesarzowej Marii, trafił do Hiszpanii.

Cesarzowa - córka Karola V - odznaczała się głęboką pobożnością w duchu kontrreformacyjnym, właściwą dla tej gałęzi Habsburgów. Jej brat, Filip II, ufundował m.in. klasztor-rezydencje w Eskurialu, natomiast siostra - Joanna Austriacka (1535-1573) - m.in. karmelitański konwent Las Descalzas Reales w Madrycie (1555-1573). Ta niezwykła inwestycja - pomyślana jako zespolenie ogólnodostępnego kościoła, klauzurowego klasztoru, rezydencji monarszej, apartamentów dla członkiń rodziny królewskiej, sierocińca, szkoły, hospicjum, wraz z koniecznym zapleczem gospodarczym - powstawała stopniowo, wspomagana także przez krewnych fundatorki. Jedną $\mathrm{z}$ pierwszych stała się cesarzowa Maria, która wieloletnie związki z konwentem przypieczętowała wola, wyrażoną w testamencie, pochowania w murach klasztoru. Maria zasilała konwent licznymi darami, w tym wielką ilością relikwii, pozyskiwanych nie tylko w Rzymie. Wśród ostensoriów $\mathrm{z}$ daru cesarzowej zachowanych w Monasterio de las Descalzas Reales w Madrycie zwraca uwagę okazały późnogotycki relikwiarz w kształcie ręki, który już na pierwszy rzut oka różni się od wyrobów złotnictwa hiszpańskiego, a przy bliższym oglądzie okazuje się fundacja zajmującego nas tu kanonika. Upewnia o tym herb na dwóch spośród sześciu tarcz u podstawy, a przede wszystkim inskrypcja donacyjna $z$ datą 1499 (i1. $1-2)^{26}$.

Wysmukly relikwiarz ma kształt prawego przedramienia, z dłonią ujętą w geście błogosławieństwa. Wspiera się na niskim, sześciobocznym cokole z gładką krawędzią ażurowym fryzem z rzędem rombów z wpisanymi maswerkowymi rozetami. Powyżej gładkie przewężenie, zwieńczone odlewanym fryzem $z$ motywem kwiatów na lodyżkach, na przemian wyższych i niższych. Fryz, wzbogacony sześcioma identycznymi figurkami (półpostaciami) aniołów-tarczowników, ujmuje dolną część przedramienia, okrąglego w przekroju, w całości pokrytego rytowanymi motywami architektonicznymi: łuki ostre z maswerkiem, przedzielone pinaklami, u szczytu wzbogacone kwiatonami. Figurki tarczowników, umieszczone w narożnikach, podkreślają tektonikę wielobocznego cokohu, płynnie przechodzacego w okragłą w przekroju, dolną część przedramienia. Na zakończonych półokragło tarczach widnieją trzy herby: papieża Aleksandra VI Borgii (1492-1503), Władysława Jagiellończyka (1456-1516) króla Czech (od 1471) i Węgier (1490), oraz samego Hermanna - z motywem stykających się ze sobą trzech sześcioramiennych gwiazd. W tle herbów zachowane resztki granatowej emalii.

Środkowy, najwyższy segment przedramienia tworzy kryształowy cylinder ujęty trzema pionowymi listwami z koronką z drobnych listków na krawędziach; na końcach listew zawiasy. Górna i dolna krawędź cylindra podkreślona grubym drutem, ujętym analogicznymi koronkami. Brzegi górnego, lekko zwężającego się segmentu przedramienia pokrywają rytowane fryzy z prostych promieni; między nimi inskrypcja fundacyjna gotycką minuskułą w czterech rzędach, rozdzielonych gładkimi pasami: bra[c]hium divi sebastiani martiri / ioahnn[e]s herma[n]i de-

${ }^{25}$ K. Enge lbert, Caspar von Logau, Bischof von Breslau (1562-1574). Teil I. Ein Beitrag zur schles. Reformationsgeschichte, Breslau 1926, s. 71-72.

${ }^{26}$ Srebro częściowo złocone, kute, odlewane, rytowane, cyzelowane, kryształ szlifowany, ślady emalii, kamień jubilerski. Wys. $53 \mathrm{~cm}$; szer. stopy $12,5 \mathrm{~cm}$. Nr inw. 00610863. 
cretoru[m] docto $[\mathrm{r}]$ / custos et canonic [us] wratislaviensis / decoravit $1499^{27}$. Starannie wymodelowana dłoń, z zaznaczonymi wszystkimi szczegółami anatomicznymi, przedstawiona w geście błogosławieństwa. Dwa ostatnie palce przygięte, na kciuku nałożony pierścień z błękitnym kamieniem jubilerskim w pełnej oprawie; między kciukiem i palcem wskazującym umieszczona pełnoplastyczna figurka św. Sebastiana. Święty w zbroi z narzuconym płaszczem, w kapeluszu na głowie, z piórem strzały w rękach.

Zabytek zachował się w bardzo dobrym stanie; jedynie emalia na tarczach herbowych uległa niemal całkowitemu wykruszeniu, a ze strzały - atrybutu św. Sebastiana - pozostało pióro. Brak też relikwii.

Pomimo rozbieżności między datą na relikwiarzu (1499) a zapisami w protokołach wrocławskiej kapituły o darze Hermanna z r. 1502 tożsamość madryckiego relikwiarza $z$ fundacją opisaną we wspomnianych aktach nie ulega wątpliwości. Przy tak okazałym, ergo bardzo kosztownym dziele złotniczym kanonik nie mógł niemal równocześnie pokusić się o dwa ostensoria zawierające relikwie tego samego świętego. $Z$ archiwaliów nie wynika, kiedy Hermann zlecił sporządzenie relikwiarza, ale inskrypcja fundacyjna to jednoznacznie przesądza.

Madrycki zabytek już kilkakrotnie był przedmiotem zainteresowania badaczy. Eksponowany na wystawach w 1941, 1992 i 1997 r., ostatnio został obszernie skomentowany przez Jose Manuela Cruz Valdovinosa, który ze znakiem zapytania związał go z wrocławskim warsztatem Oswalda Rothego ${ }^{28}$. Jednakże zlotnik ten uzyskał prawa miejskie dopiero 20 grudnia $1503 \mathrm{r}^{29}$, a zatem nie wchodzi w rachubę jako twórca dzieła opatrzonego datą 1499. Pomijając szereg błędów w pracach Cruz Valdovonosa, zwłaszcza określenie Hermanna jako kanonika bratysławskiego, trafnie wskazał on dwie najbliższe analogie madryckiego relikwiarza, zachowane w skarbcu katedry we Wrocławiu. Obie bezsprzecznie zaliczają się do czołowych późnogotyckich kreacji jednego z ważniejszych podówczas środkowoeuropejskich ośrodków złotniczych.

Pierwszym jest relikwiarz ręki św. Stanisława, sprawiony w r. 1465 m.in. przez jej wikariusza Jakuba Ketschera (il. 3) ${ }^{30}$. Daleko idące podobieństwa dotyczą kompozycji poszczególnych segmentów, zwłaszcza sposobu osadzenia kryształowego cylindra i posługiwania się rytowaną dekoracją, a także zbieżności wielu detali, m.in. ażurowego fryzu maswerkowego z rzędem rombów, półpostaci anio-

${ }^{27}$ Ze względu na niemożność weryfikacji odczytu, niniejsza lekcja nie uwzględnia znaków przestankowych zastosowanych w inskrypcji.

${ }^{28}$ F. J. C a r rillo, Relación histórica de la Real Fundación de Monasterio de las Descalzas de Santa Clara de la Villa de Madrid, Madrid 1916, passim; Exposicion de orfebreria y ropas de culto, Madrid 1941, I, relikwiarz nr 75; Arte y Cultura en torno a 1492, Sevilla 1992, s. 283, poz. 201 [oprac. J. M. Cruz Valdovinos]; J. M. Cruz Valdovinos, Platería europea en España (1300-1700), [Madrid 1997], s. 19, 78-80, poz. 15; A. Ga r c i a S a n z, L. $\mathrm{S}$ à $\mathrm{c}$ h e $\mathrm{z} H \mathrm{H} \mathrm{r}$ àn $\mathrm{de}$, The Convents of Las Descalzas reales and La Encarnación (Two Cloistered Convents in Madrid), Madrid 1999, s. 36.

${ }^{29}$ E. H intze, Die Breslauer Goldschmiede. Eine archivalische Studie, Breslau 1906, s. $145 ; \mathrm{R}$ e gu $1 \mathrm{sk}$ a 2001 , s. 70 .

${ }^{30} \mathrm{R}$ e g u l s k a 2001, s. 94-95, 151, poz. 78, il. 226-227, 231 (tam wcześniejsza literatura). W świetle zebranego tam materiału zabytkowego, nieuzasadnione wydaje się opatrywanie znakiem zapytania Wrocławia jako miejsca powstania relikwiarza-J. M. F r i t z, Goldschmiedekunst der Gotik in Mitteleuropa, München 1982, s. 271, poz. 601. 
łów-tarczowników, figurki świętego pomiędzy palcami dłoni, umieszczenia pierścienia na kciuku. Zważywszy na dość znaczną odległość w czasie powstania ostensorium św. Stanisława i madryckiego relikwiarza - 34 lata - trzeba podkreślić zachowawczość form tego ostatniego. Jedynie stylizacja plastycznych kwiatów w zwieńczeniu cokołu, rytowanych maswerków oraz kompozycja postaci św. Sebastiana - zdradzają cechy przełomu XV i XVI stulecia. Relikwiarz św. Sebastiana sprawia wrażenie wzorowanego na ostensorium św. Stanisława; powodem takiego zabiegu było najpewniej przeznaczenie wszystkich trzech katedralnych relikwiarzy, które - zgodnie z powszechną praktyka - były razem wystawiane na oltarzu w czasie największych świąt.

Zachowawczość form madryckiego dzieła jest szczególnie widoczna w zestawieniu z drugą wskazaną analogia, relikwiarzem św. Jana Chrzciciela fundacji kanonika Jana Scheuerleina z r. 1512, ze znakiem warsztatu Oswalda Rothego (il. 4) ${ }^{31}$. Przy zbieżności kompozycji i niektórych rozwiązań formalnych - szczególnie motywu ażurowego fryzu maswerkowego i opracowania dłoni - łatwo zauważalne są różnice: większa przysadzistość dolnej partii dzieła Rothego, plastycznie ukształtowanej w formie pomarszczonego rękawa, ujęcie kryształowego klosza wiązkami kolumienek na wspornikach i wprowadzeniem figurek w ich zwieńczeniach, a zwłaszcza posłużeniem się renesansową majuskułą w inskrypcji fundacyjnej. Także zasób, a zwłaszcza stylizacja ornamentów zdradza przynależność relikwiarza św. Jana do kreacji XVI w. Różnica trzynastu lat od sprawienia relikwiarza św. Sebastiana jest znacznie widoczniejsza w dekoracji ostensorium Rothego niż niewielkie odmienności formy obu XV-wiecznych dzieł. Z tego też powodu ornamentacja madryckiego relikwiarza ma sporo precedensów w innych późnogotyckich wyrobach wrocławskiego środowiska. Tytułem przykładu można wskazać baldachimy rozpięte między fialami, rytowane u szczytu płaszcza stopy niedawno odnalezionego kielicha fundacji kanonika Apiciusa Colo z r. $1507^{32}$ czy kielicha z warsztatu Andreasa Heideckera z r. $1517^{33}$ - analogiczne względem dekoracji dolnej części naszego relikwiarza. Kompozycja odlewanej koronki w zwieńczeniu cokołu relikwiarza św. Sebastiana zbliża się do motywu łodyżek z wydatnymi kwiatami, dołem oplecionych na poziomej gałązce, zdobiącego koszyczek czary złotego kielicha fundacji Jana Hoffmanna (po $1501 \mathrm{r}$.) ${ }^{34}$.

Omówiony relikwiarz należy do dużej grupy środkowoeuropejskich wyrobów złotniczych rozproszonych po świecie i przeważnie pomijanych, nie tylko w polskich badaniach naukowych. W Eskurialu zachowały się inne gotyckie relikwiarze ręki pochodzące $z$ tego regionu. Szczególnie cenna jest złota oprawa przedramienia Św. Błażeja z inskrypcją:

HOC BRACHIVM SANCTI BLASII FECIT ORNARI/WENCESI,AIVIS TERCIVS BOEMIE ET POLONIE/REX ANNO REGNORV'SVORV PRIMO [1306],

\footnotetext{
${ }^{31}$ R e g u 1 s k a 2001, s. 155-156, poz. 84, il. 228-230 (tam wcześniejsza literatura).

${ }^{32}$ Kraków, Zamek Królewski na Wawelu, nr inw. 8658 - M. A d a m s k a, D. N o w a c k i, Nieznany późnogotycki kielich w Skarbcu Koronnym na Wawelu [w druku].

${ }^{33}$ Wschowa, kościół św. Stanisława - R e g u l s k a 2001, s. 178, poz. 123, il. 103-105.

${ }^{34}$ Wrocław, katedra - R e gu l s k a 2001, s. 153-154, poz. 82, il. 113, 115.
} 
zdobiona dwiema plakietami w emalii z przedstawieniem modlącego się króla - arcydziełami XIV-wiecznego emalierstwa ${ }^{35}$. Także do Czech odnosi się inskrypcja z relikwiarza ręki św. Jana: BRACHIUM SANCTI IOHANNIS QUIN/QUE . SANTORUM PATRONORUM BOHEMIE, o którym wiadomo, iż 9 kwietnia 1572 r. miał zostać przysłany z Polski dla Filipa II, gromadzącego w Eskurialu relikwie z całej Europy ${ }^{36}$. Zabytek ten, choć skromny, o nie wyrafinowanej formie, znacznie poszerza nasza wiedzę o XIV-wiecznych wyrobach złotniczych mających historyczny związek z naszym krajem.

Dla badań nad złotnictwem śląskim szczególne znaczenie ma poszukiwanie dzieł niedostatecznie zinterpretowanych w kontekście już znanego materiału zabytkowego. Chodzi m.in. o frapujące, dotąd słabo rozpoznane exempla gotyckich klejnotów z tego terenu: XIV-wiecznego zespołu blaszek ze skarbu opolskiego ${ }^{37}$ i pierścieni wiązanych ze skarbem ze Środy Śląskiej ${ }^{38}$, czy XVI-wiecznego (?) klejnotu z figurką tronującej Matki Boskiej, opatrzonego domniemaną cechą złotniczą Legnicy ${ }^{39}$. Trzeba odnotować szczególne zaniedbania w konfrontowaniu śląskich sreber $\mathrm{z}$ zabytkami $\mathrm{z}$ innych regionów artystycznych ${ }^{40}, \mathrm{w} c z y m-$ mamy

35 Patrimonio Nacional, Relicario del Monasterio de San Lorenzo el Real, nr inw. 10044180 - El Arte de la Plateria en las Colecciones Reales, Sala de Exposiciones Banco Herrero, Oviedo, [Madrid 1997], s. 20, poz. 1; Cruz Valdovinos 1997, s. 18.

${ }^{36}$ Patrimonio Nacional, Basilica de San Lorenzo, Relicario Bajo de San Jeronimo, nr inw. 10044268. Według informacji Fernando A. Martin, Kustosza Patrimonio Nacional, jest to jedno z czterech niemal identycznych ostensoriów pozyskanych z Polski przez Filipa II.

${ }^{37}$ Przed 1945 w Kunstsammlungen der Stadt Breslau - Ch. Gündel, Die Goldschmiedekunst in Breslau, (Die Goldschmiedekunst der deutschen Städte), Berlin [1942], tabl. 3.

${ }^{38}$ Jeden $z$ szafirem, datowany na 1. pol. w. XIV; drugi z przedstawieniem słońca i księżyca, przez Rainera Sachsa odnoszony do Muscho (Mojżesza), ostatniego średniowiecznego właściciela skarbu - Klejnoty monarsze. Skarb ze Środy Slaskiej, red. J. Pietrusiński, J. Witkowski, Wrocław 1996, s. 45-46, 124, nr 7, il. 117; E. G a j e w s k a-Pror o k, Skarb ztotych ozdób ze Srody Slaskiej, [w:] Bizuteria w Polsce. Materiaty z sesji naukowej zorganizowanej przez Muzeum Okregowe w Toruniu oraz Torunski Oddziat Stowarzyszenia Historyków Sztuki 20-21 kwietnia 2001 roku, red. K. Kluczwajd, Toruń 2001, s. 41, 46, 54, i1. 34-35.

${ }^{39}$ Kolonia, Museum für Angewandte Kunst, nr inw. G 407 - A. B. Chadour, R. J op pi e n, Schmuck. 1, Hals-, Ohr-, Arm- und Gewandschmuck [Kunstgewerbemuseum der Stadt Köln], Köln 1985, I, s. 199, 582, poz. 92.

${ }^{40} \mathrm{R}$ e guls k a 2001 ogranicza się w tym względzie do jednozdaniowych ogólników (s. $57,59,66,109)$, wyłączając z rozważań kilka dzieł, wiązanych ze Śląskiem na podstawie analizy formalnej lub okoliczności historycznych (przywiezienie ze Śląska po r. 1945), por. m.in. kielich z Zar (1384 r.) - Zbiory Muzeum Archidiecezjalnego w Katowicach, Katowice 1995, s. 16, 112, 173; K. S z c z e p kow sk a - N a l i w a je k, Gotycki kielich miszalny z fundacji Mikotaja i Bernharda Stewiczów, [w:] Festina lente. Prace ofiarowane Andrzejowi Fischingerowi w siedemdziesiquta rocznice urodzin, red. M. Piwocka, D. Nowacki, Kraków 1998, s. 43-48; kielich w Kielcach (koniec w. XIV) - Corpus Inscriptionum Poloniae, I, Województwo kieleckie, red. J. Szymański, I, Miasto Kielce i powiat kielecki, wyd. B. Trelińska, Kielce 1975, s. 83, poz. 53; Skarby Kielc, red. Z. Nocoń, D. Olszewski, Kielce 1992, s. 51; Ornamenta Ecclesiae. Sztuka sakralna diecezji kieleckiej [Muzeum Narodowe], Kielce 2000, s. 99, 115, poz. 146 (oprac. K. Myśliński); kielich w klasztorze OO. Franciszkanów w Krakowie (1516 r.) - Katalog Zabytków Sztuki w Polsce, IV, Miasto Kraków, 2, Kościoly i klasztory Śródmieścia, l, red. A. Bochnak, J. Samek, Warszawa 1971, s. 129, il. 745; J. T. N ow a k, W. T u r d z a, Skarby krakowskich klasztorów, Kraków 2000, s. 223, 234, 242, il. 254. Nawet gdybyśmy nie mieli tu do czynienia z kreacjami wroclawskich złotników - wyroby te dowodziłyby śląskich wpływów poza granicami prowincji 
nadzieje - walnie pomoze ujawnienie kolejnych, uznanych za zaginione, kreacji wrocławskich złotników: relikwiarzowych figurek Matki Boskiej ${ }^{41}$ oraz św. Anny Samotrzećc ${ }^{42}$, czy relikwiarza św. Sebastiana będącego przedmiotem niniejszego komunikatu.

\section{St. Sebastian's Silver Reliquary from 1499 Summary}

Johannes Herman (ca 1435-1504), canon of the Wrocław Cathedral Chapter has been known so far from references included in the records of the Chapter's meetings. An entry of September 16, 1502 reads that Herman presented the Cathedral with a beautifully embellished reliquary of St. Sebastian's hand, made of gilded silver, with the intention of redeeming his soul and celebrating the Saint's relics. Simultaneously, he was asking the Chapter to establish St. Sebastian's feast (January 20) as dupliciter (with three readings), and proposed that the offering on that day be used to cover students' scholarship expenses. Canons accepted the gift and promised to comoperate with bishop Johann Roth, whose duty was to establish the rite. At the Chapter's meetings of December 22, 1503 and January 5, 1504, Herman followed up the cause. He confirmed his wish to support the students of the Cathedral School and finally stated that he would sell the reliquary to meet additional financial demands made by the Chapter. Both sides remained devided on the issue. The reason why there are no more records on the matter was Herman's forthcoming death.

The above-mentioned reliquary was kept in the Cathedral treasury; the fact mentioned in the records on the occasion of Maximilian II' visit, then the Czech and Hungarian king, to Wrocław in December 1563. The monarch asked the Chapter to show the relics to his wife, Mary. Canons decided to show St. Jadwiga's hand and St. Sebastian's arm relics. In a letter of February 9, 1564 written by Wroclaw bishop Caspar von Logau to the Chapter deans we read about Maximilian's wish to purchase the relics. Other relics or a financial compensation were considered to pay for the transaction. There are no records on actual negotiations, the transaction, however, was completed as the reliquary of St. Sebastian was given by queen (later empress) Mary to Spain.

Among ostensories presented by the empress as gifts and preserved at Monasterio de las Descalzas Reales in Madrid is a splendid hand reliquary in the late Gothic style which turns out to be identical with the one mentioned in the records of the Wroclaw Chapter. The inscription bears the name Herman and date 1499 .

Cruz Valdovinos had already pointed at its two closest analogies preserved in the Cathedral treasury in Wrocław - St. Sebastian's and St. John the Baptist's hand reliquaries. The paper describes interdependencies of the three works of art and calls for further research, especially on the relation of the Silesian Gothic goldsmith's work to others centres primarily central European.

${ }^{41}$ Przed r. 1945 w Schlesisches Museum für Kunstgewerbe und Altertümer we Wrocławiu, obecnie Kraków, Muzeum Narodowe, nr inw. MNK-IVz-1067, dar Tadeusza Dobrowolskiego; por. Regulska 2001, s. 86-87, 176, poz. 120, il. 207; K. Szczepkowska- N a li w a je k, Zwiazki rzeźby i plastyki ztotniczej w Polsce na przetomie XV i XVI wieku, „Teka Komisji Historii Sztuki”, IX, 2002, s. 99-101, i1. 4. Od kwietnia do listopada 2004 r. eksponowana w Skarbcu Koronnym na Wawelu.

${ }^{42}$ Przed r. 1945 w kościele św. Mikołaja w Pyskowicach, obecnie w warszawskich zbiorach prywatnych-S zc ze p k ow s ka-N a l i wa jek 2002, s. 105, 107-109, il. 10-11. 


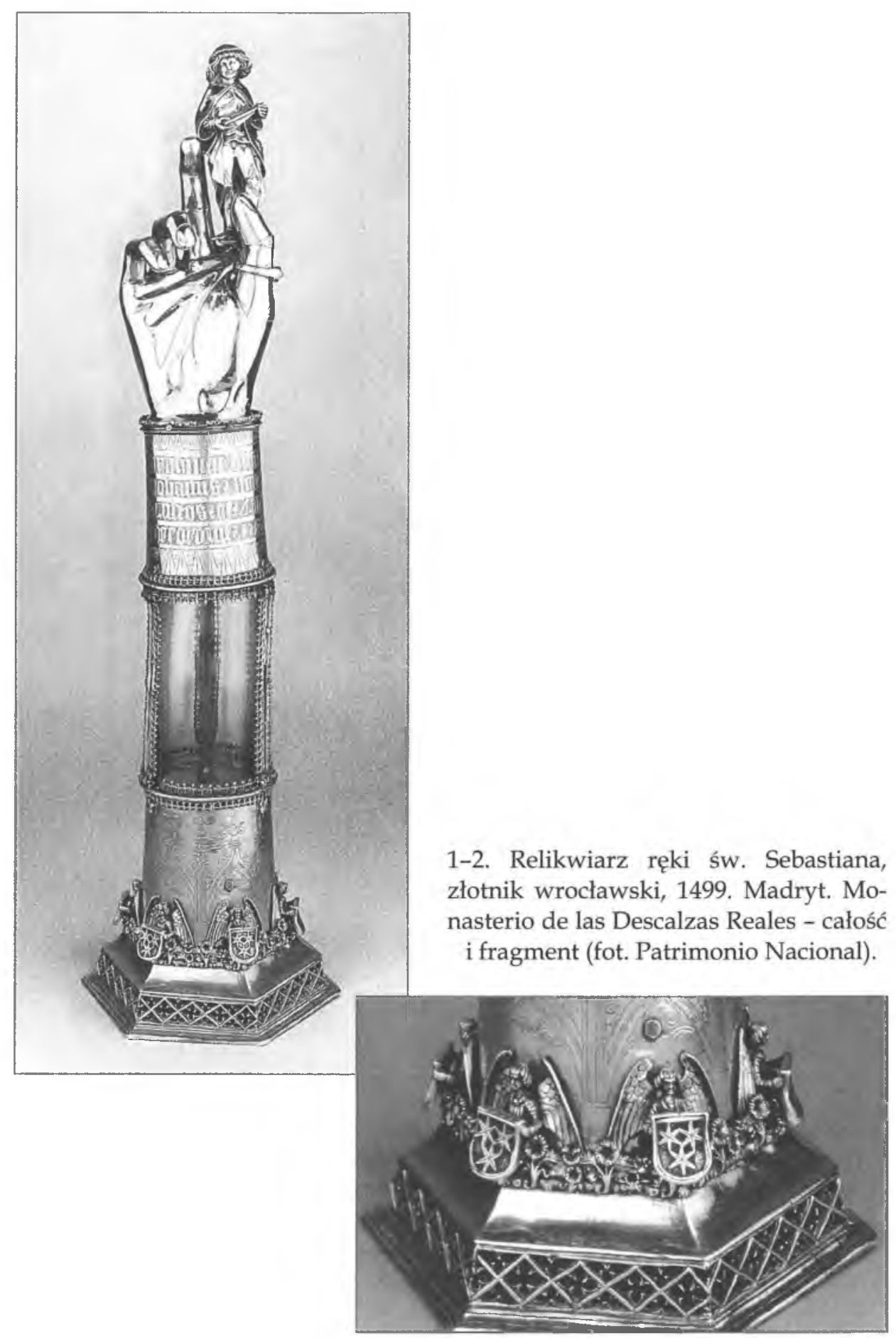




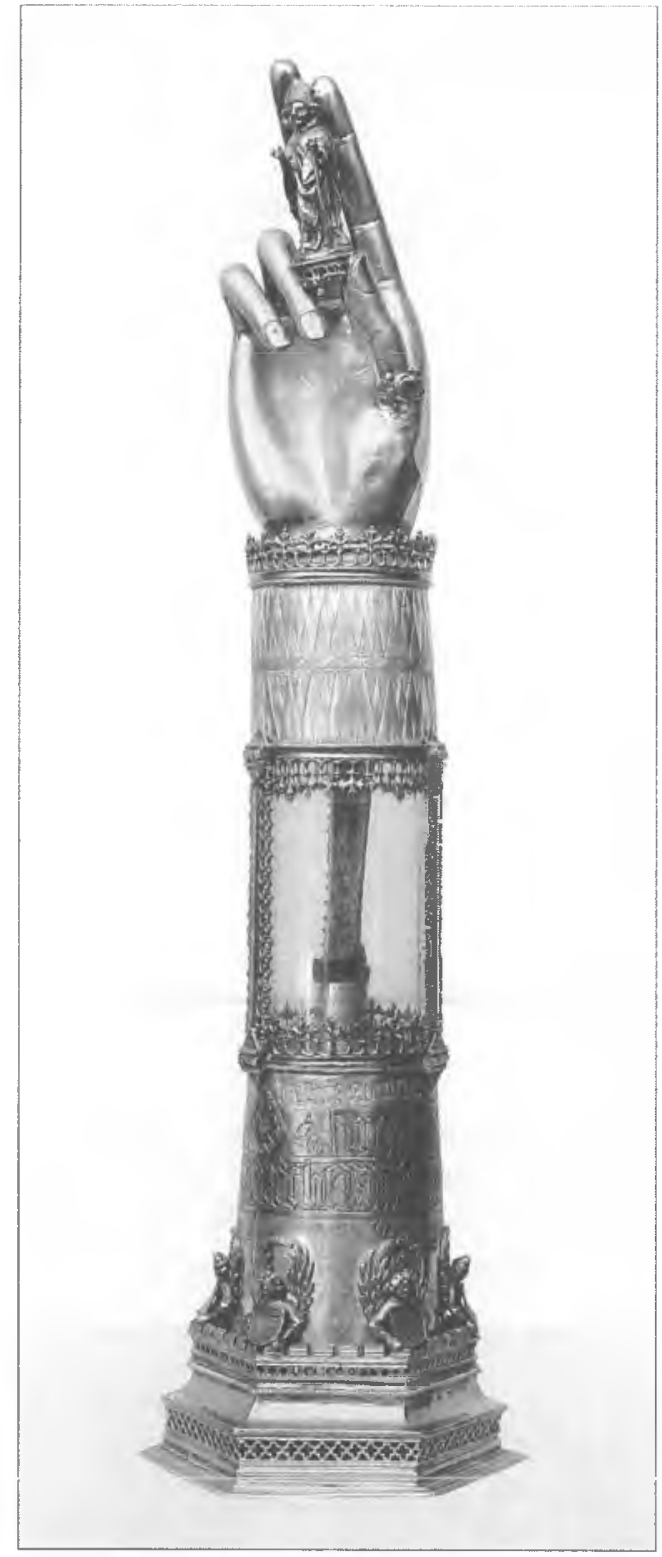

3. Relikwiarz ręiki św. Stanisława, złotnik wrocławski, 1465. Wrocław, katedra (wg E. Hintze, K. Masner, Goldschmiedearbeiten Schlesiens, Breslau 1911).

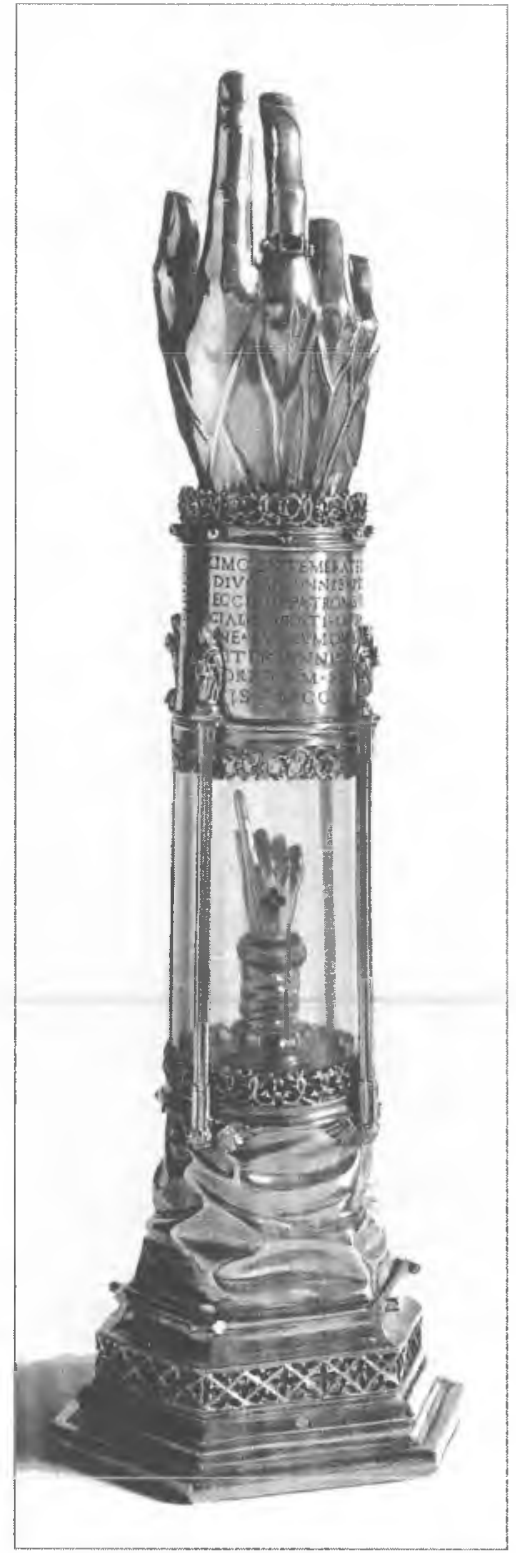

4. Relikwiarz ręki św. Jana Chrzciciela, złotnik wrocławski Oswald Rothe, 1512. Wrocław, katedra (wg Gündel 1942). 